\title{
INHERITING DU BOIS ${ }^{1}$
}

\author{
Lawrie Balfour \\ Department of Politics, University of Virginia
}

\section{INTRODUCTION}

What would it mean to treat W. E. B. Du Bois as a "living political thinker," Tommie Shelby asks. The formulation of the question indicates one answer: acknowledging Du Bois's twofold legacy for political theory and philosophy. On the one hand, his body of work as a political theorist is rich and provocative enough that it ought to be, as Robert Gooding-Williams (2009) urges, the subject of serious inquiry in its own right. On the other hand, engaging Du Bois as a political theorist enables contemporary scholars to reflect on the political challenges of our own time, even when Du Bois offers answers we would not own for ourselves. Perhaps most crucially, taking Du Bois's work seriously requires a rigorous engagement with the past and an active refutation of declarations of a "postracial" age that belie yawning racial inequalities, the continuing devaluation of non-White lives, and the unredressed injuries- to American citizens, to the polity itself, and to women and men well beyond U.S. borders-of White supremacy. All of the participants in this symposium would, I think, endorse this view in its broadest strokes. But to inherit Du Bois as a political thinker is also to participate in an ongoing and often contentious conversation about race, democracy, and Du Bois himself. Accordingly, my comments will focus on two clusters of issues. The first is raised by Rogers Smith's and Tommie Shelby's vigorous disagreement with the idea of Black reparations that I explore in the second chapter of Democracy's Reconstruction. The second involves a set of unresolved tensions bequeathed by Du Bois and addressed in Gooding-Williams' extraordinary book and Cristina Beltrán's meditations on the Afro-modern political tradition and Latino politics today.

\section{THE FUTURE OF REPARATIONS?}

Together, Smith and Shelby strike what appears to be a fatal blow to reparations as a democratic idea: it is a political nonstarter resting on a philosophically incoherent conception of justice. Before turning to their arguments directly, I want to clarify that this essay will not survey the range of possible programs of financial and symbolic redress that might serve as reparations for slavery and Jim Crow. Instead, I focus on what I call a language of reparations, a form of public discourse that joins an 


\section{Lawrie Balfour}

acknowledgment of the injuries done to the slaves and their descendants and their contributions to the polity, on the one hand, to an account of a more democratic future, on the other. As Smith and Shelby demonstrate with devastating clarity, this is a hazardous project. Nonetheless, I aim to show that there are strong answers to the concerns they rightly raise. I will start with Smith's reservations and then turn to Shelby's, although my comments will overlap at some points.

Let me begin with an objection raised in both essays, the claim that "talk of reparations begins with and points continuously backward." One way to reply is to examine the substance of actual reparations arguments. In the U.S. context, the most famous - or infamous - of these may be the Black Manifesto. When James Forman interrupted services at Riverside Church in 1969 to demand \$500 million from White churches and synagogues, he recalled centuries of racist exploitation. Yet when we consider the specifics, we find that the Manifesto envisioned the use of the money for, among other things, the development of media outlets, a Southern land bank, training and research programs and the founding of a new Black university, assistance to the National Welfare Rights Organization, and a fund to support exploited and striking workers (Forman 1997, pp. 543-550). Hardly a backwardlooking plan of action. Forman's interest and that of the National Black Economic Development Conference, which drafted the Manifesto, was the present and future condition of Black America, and he explicitly states that reparations is not an end in itself but a vehicle for liberation. Of course, the failure of the Manifesto to produce lasting benefits may make Smith's point that reparations talk is "unlikely to engage political attention, much less inspire political change." Yet, if we disentangle the concept of reparations from controversies over Forman's tactics or his revolutionary agenda, we might conceive an approach that similarly links historically oppressive practices and institutions to concrete, forward-looking proposals. In other words, if we connect talk of reparations to the unfinished project of democratic reconstruction and to Du Bois's studies of it, we may see more clearly why public investment in the most vulnerable Black communities is essential to the common good.

Smith also notes that "talk of 'reparations' is inevitably heard as implying [White Americans'] personal responsibility for specific harms past and present." As he observes, the vehemence of White objections to reparations-even to official apologies for slavery and Jim Crow-threatens to derail any constructive effort to think through ways to improve conditions now. My response is twofold. First, I agree that the heat such discussions generate undermines the aspiration to effect social change, and that it often reflects a sense of personal affront- "I did not own slaves!" "My ancestors were immigrants." "I've worked hard for everything I have." The language of reparations is undeniably a provocation, but I am not sure that it is distinctly unproductive. In a political culture in which references to personal responsibility are omnipresent and in which these references are especially pernicious when the responsibility of non-White citizens is either explicitly or tacitly at issue, a language of reparations might open the door to reconsideration of assumptions about individual achievement and personal responsibility that go unnoted and unchallenged in everyday political talk. It might spark critical reflection, for instance, on a political culture in which the election of the first African American president could give rise to a chorus of "no more excuses," as if the one followed logically from the other. The point is not to turn an accusing finger on White Americans but to orient all citizens differently toward the history and substance of the idea of personal responsibility.

Second, reparations discourse offers a means of exploring collective responsibility without attributions of guilt. Where the latter focuses on individual victims and perpetrators and the establishment of clear causal lines from past crimes to present 
conditions, the former considers the legacies of slavery as part of the constellation of obligations and benefits bequeathed from one generation of citizens to the next. Departing from what some have called a juridical or tort model of reparations, the concept that I draw from Du Bois's rewriting of Reconstruction history seeks collective opportunities for refounding the polity in more democratic ways. In this regard, it might be the basis for alternative "stories of peoplehood" (Smith 2003). Such stories would own, rather than disavow, the ethically mixed character of the national inheritance. They would contest not only the implicitly and explicitly racially demeaning narratives that still seek to cast immigrants, welfare recipients, prisoners, and the poor as anticitizens but also the dishonest narratives of racial transcendence that invoke the crimes of the past only to herald their overcoming.

Where Smith contends that it is more efficacious, politically, to begin with citizens' concern for contemporary problems and then introduce historical accounts of racial oppression, I ask whether the reverse could be true. On the one hand, it is not clear that the political will exists to face the tragic evidence of our collective failureincluding inadequate schools and housing, mass incarceration, poor public health, and the racial wealth gap-even in the absence of controversial claims about genealogy. On the other hand, the recent wave of official apologies and expressions of regret for slavery and Jim Crow indicate at least a nominal openness to revisiting the presence of the past. Further, a reticence "to lead with distant history" on the part of citizens interested in a more racially just future may cede the shape of public narrative to figures who would deny the fundamental role of race in the constitution of the United States. In August 2010, for example, when Glenn Beck rallied for honor on the steps of the Lincoln Memorial on the anniversary of the 1963 March on Washington for Jobs and Freedom, he did not follow Martin Luther King, Jr., by invoking the grand statue to recall the unfinished promises of emancipation. Instead, Beck used the occasion to discredit self-critical stories of peoplehood: "This country has spent far too long worrying about scars and thinking about scars and concentrating on scars. Today, we are going to concentrate on the good things in America" (Zernike et al., 2010). Whose scars, one wonders, are undeserving of concern? Whose scars are explicitly elided, moreover, when the idea of a slaveless Confederate cause is once again in the news (Seelye 2010) and public figures, including the former Senate Majority Leader and past and prospective candidates for the presidency, express nostalgia for slavery and Jim Crow? In such a political context, the language of reparations might be better thought of as a democratic counterweight to wishful histories, an alternative to the pretense of unity rather than a source of avoidable division.

Where Smith queries the political viability of reparations arguments, Shelby outlines related but distinct concerns about their philosophical underpinnings. At the heart of his critique is the claim that "the language of reparations obscures contemporary demands for distributive justice." Reparations, in Shelby's view, serve the exclusively compensatory or corrective function of fixing the damage of past injustice. Demands for political and economic equality, by contrast, not only require no account of historical injury but may be diminished by the introduction of irrelevant considerations of such injury. Economic injustice is wrong, he maintains, regardless of its connections to racial slavery. And democratic citizens deserve full enjoyment of their rights, whether or not they "earned" the gratitude of the nation through their sacrifices. My response proceeds along three tracks: first, I show how a reading of Du Bois troubles the hard line Shelby draws between compensatory and distributive justice; second, I note that Shelby's emphasis on economic inequality misdescribes the legacies of slavery; and third, I ask why a language of reparations threatens other kinds of democratic discourse. 


\section{Lawrie Balfour}

By defining reparations exclusively as a matter of compensatory justice or corrective justice, Shelby positions himself on one side of a debate about whether reparations are primarily backward- or forward-looking that is far more contested than his comments imply. More importantly, however, the narrowness of the definition obscures one of the crucial lessons of Du Bois's work. Although Du Bois does not himself use the language of reparations, I explore it as a vehicle for thinking through the living legacies of racial slavery, a present-past in which compensatory and distributive concerns are thoroughly entangled with each other. This orientation is in keeping with what Pablo de Greiff (2007) calls "reparations as a political and not a juridical project" (pp. 156-157). More specifically, Du Bois's rewriting of the history of slavery, Reconstruction, and their aftermath trains our sights not only on what justice entails but also on what democracy demands. He considers how a more thoroughgoing accounting of the injuries of the past and of the accomplishments of African Americans contributes to "the effort to reconstruct the basis of American democracy" (Du Bois [1935] 1992, p. xix). Accordingly, the political import of his historical claims is more helpfully considered via the concept of transitional justice than either compensatory or distributive justice (Davis 2010; Valls 2003). And while it is true, in one sense that, as Shelby states, "being made 'whole' is not the same as being made equal," understanding reparations in political terms as part of a democratic project shifts the idea of wholeness away from the restitution of a fictive status quo ante and toward what Danielle Allen (2004) means when she talks about "wholeness" as the aspiration to become a democratic people. Like Du Bois's inquiry into the "lost promise" of Reconstruction, a language of reparations calls on us to consider what slavery meant, how it was defeated, and how its defeat bequeathed new regimes of racial power, whose incomplete eradication in the civil rights era we are still wrestling with now; in this way, it resonates with Allen's (2004) admonition "to see a democracy in a moment of unknitting and reweaving" (p. 24).

Second, Shelby's argument would have more traction if my own were exclusively or primarily concerned with economic inequality. While he rightly notes that economic injustice is one of the motivations of my study of Du Bois, I nonetheless contend that one of the lessons of Du Bois's work is that devaluation of non-White, non-Western lives is fundamental to modern life and poses a persistent obstacle to the realization of more egalitarian ways of life. A language of reparations vivifies the connections between centuries of unjust enrichment on the backs of Black labor and the lasting dishonor produced through the alchemy of race and slavery and its twin, the magical property of Whiteness. It offers an alternative to race-blind formulations that risk reinforcing popular connections between current patterns of inequality and cultural or biological deficiency.

Third, nothing in my book is meant to suggest that past injustices supply the only grounds on which arguments against unjust social arrangements can be made. I concur with Shelby that "if poor Blacks need greater resources to achieve full citizenship, then they are owed this investment regardless of whether their ancestors were enslaved." Equally, the claims of poor Whites or of any economically disadvantaged citizens neither rely upon proof of historical injustice nor are diminished by arguments about the long shadow of slavery and Jim Crow. Critics of American democracy's unfulfilled promises ought, instead, to make use of the broadest array of plausible arguments, rather than limiting themselves to claims about distributive justice.

Finally, in response to both Smith and Shelby, I would like to affirm that a language of reparations has the virtue of moving the conversation about race and democracy beyond the United States in ways that not only challenge the bounded- 
ness of American politics but also offer opportunities to learn from concrete historical experiments elsewhere. In this way, it answers Gooding-Williams' persuasive argument against a politics premised on exclusion from the dominant society and heeds Smith's advice to consider the international and transnational dimensions of racial politics. It pays tribute, furthermore, to Du Bois's relentless efforts to call attention to the color line that belts the world and to situate the prospects for American democracy within a global historical framework. In this light, it is instructive that the Oxford Handbook of Reparations (De Greiff 2006) devotes only a small fraction of its one thousand pages to the United States and that the laws and commission reports it reproduces come in large measure from Africa and South and Central America. Attending to the accomplishments and shortcomings of those efforts both decenters the United States as the primary referent for democratic thought and offers a promising avenue for comparative inquiry.

Nowhere do I argue for an obligation to embrace the idea of reparations. Before democratic theorists dismiss it as unworkable, however, we have a responsibility to examine it carefully and to consider why it has, for so long, been judged unthinkable. I recognize the dangers. Not only is talk of reparations potentially politically regressive for the reasons Smith and Shelby discuss, but we can add reasons they kindly omitted from their remarks. Still what reparations offer, uniquely, is a political language that connects future democratic possibility to an acknowledgment of constitutive injustices of the past. Calling attention to the racial politics of time, it disallows the evasions that characterize defenses of "diversity" as a timeless value. Reparations is an imperfect vocabulary, but may be the best available right now. If there is another, more effective way "to bring race and racial injustice into our accounts of past and present democracy so that we move ourselves and others to think what can and should be done next," as Smith suggests, then I am all for it.

\section{THINKING HISTORICALLY WITH, AGAINST, AND ABOUT DU BOIS}

Gooding-Williams and Beltrán raise another set of powerful questions about inheritance. In different, but complementary, ways they ask us to consider the connections between a tradition of political thought and the shape of contemporary politics. Together, Beltrán's essay and Gooding-Williams' book press us to consider the degree to which a historical orientation occludes the distinctive political challenges of the present moment and inhibits a politics defined by plurality and collective practices of freedom. They echo Smith's and Shelby's worry that a preoccupation with the past, even a complex conception of a "present-past," may impede democratic projects in the present. As Gooding-Williams (2009) writes, a focus on the crimes of slavery and segregation may flatten the contours of Black politics and prevent us from responding to "the persistent and accelerating differentiation of African American experience" (p. 218). Better to focus on what Beltrán (2010) elsewhere calls "moment[s] of initiation" (p. 132) and the radically participatory democratic politics that, Gooding-Williams (2009) contends, is modeled in $M y$ Bondage and My Freedom (Douglass [1855] 2003).

Beyond these broad concerns about how to negotiate the tensions between plurality and memory, Beltrán's and Gooding-Williams' readings demonstrate why Du Bois's political theory itself is an ambiguous resource for contemporary democratic projects. As Beltrán observes, Gooding-Williams' "more agonistic" interpretation of Du Bois's political theory raises a forceful question about what is at stake in deriving a democratic argument from a thinker whose antidemocratic tendencies 


\section{Lawrie Balfour}

Gooding-Williams elucidates so clearly. Even if I were to say of Du Bois what Gooding-Williams says of Douglass - that "more than one mind, more than one voice, animate his intellectual career" (2009, p. 167) — this does not settle the matter.

Part of what makes In the Shadow of Du Bois so compelling is the seamlessness of the argument. On the one hand, Gooding-Williams opposes a politics that is elitedriven, animated by a strong sense of a common Black identity, and oriented toward inclusion in, rather than transformation of, American political and social life. On the other hand, he constructs a meticulous portrait of Du Bois's early political thought that shows how it is defined by each of these elements. Du Bois not only authorizes such a politics explicitly in his political theory, he reinforces its continuing hold by virtue of his stature and the shadow he still throws. Still, without denying the non- or even anti-democratic dimensions of Du Bois's early thought, is it not possible to derive a radically democratic view of popular agency, a critique of fixed conceptions of racial identity, and a powerful challenge to anomaly theories of White supremacy from these same texts? Is it responsible? My answer to both questions is yes. The value of Du Bois's legacy resides not only in its coherence but also in its productive tensions and flights of imagination. For instance, in "The Development of a People," an essay that Gooding-Williams draws upon in his account of Du Boisian leadership, Du Bois ([1904] 1997) not only promotes the role of an educated elite as interpreters of twentieth-century civilization for the masses, but he also inserts a passage entwining European modernity and the captivity and conquest of raced bodies that ought to give modern civilization's most ardent enthusiasts pause:

Across the blue waters of the Atlantic two hundred and fifty ships a year hurried to the west, with their crowded, half-suffocated cargoes. And during all this time Martin Luther had lived and died, Calvin had preached, Raphael had painted and Shakespeare and Milton sung; and yet for four hundred years the coasts of Africa and America were strewn with the dying and the dead, four hundred years the sharks followed the scurrying ships, four hundred years Ethiopia stretched forth her hands unto God (p. 248).

The juxtaposition of an aristocratic account of leadership with a tragic reading of modern civilization indicates the kind of challenge Du Bois offers contemporary democratic theory. On the one hand, there is a danger that if agonism becomes antagonism, the wealth of Du Bois's democratic insight is lost; on the other is the risk that, looking for democratic ideas in Du Bois's corpus, we find only what we want to see.

So what does it mean, in Gooding-Williams' words, to “inherit Du Bois and Douglass after Jim Crow" (2009, p. 210)? Surely, the question speaks to the legacy of two thinkers whose critical assessments of White supremacy are unparalleled. The acuity of their work as "lenses" not only into the political challenges of their times but into the challenges bequeathed to ours is enormous. Nevertheless, I am unsettled by the hold of these representative men on the political imagination. As father figures go, Du Bois and Douglass stand apart for their passionate defenses of women's rights, and both Gooding-Williams and I advance a feminist politics that refuses the masculinism of their language. Is this enough? Perhaps if the study of Du Bois and Douglass were matched by inquiry into the neglected political theory of Anna Julia Cooper, Ella Baker, Angela Davis, and others, it would allay the concern. Yet, as Beltrán points out in her incisive critique of the way that Gloria Anzalduá and other thinkers have been appropriated to lend an aura of multicultural credibility, mere inclusion is not sufficient to transform a discourse. Her comment suggests that in 
addition to the patriarchal character of so many intellectual lineages-Afro-modern political thought included-there may be a deeper contradiction between a fundamentally aristocratic field of study and the non-elite politics both Gooding-Williams and I endorse. In other words, both books may be caught in a paradox that Beltrán does not identify: how to conceive more democratic modes of political theory when our training and the norms of the profession impel us to canonize and thereby to reauthorize a genealogy of founding fathers (and mothers). The answer, I suggest, is not to abandon inquiry into the possibilities Du Bois and Douglass open for us, but to be vigorous in asking what alternatives a great-thinker approach might foreclose.

\section{CONCLUSION}

Such unresolved questions about how to remember Du Bois, like debates over the political legacies of slavery and the future of reparations, are not merely academic. Indeed, they provide fertile ground on which to argue about what a more democratic polity would look like. Martin Luther King, Jr. understood this when he took the stage at Carnegie Hall to remember Du Bois in 1968. As King (1970) insisted that Du Bois's life spoke to "our tasks of emancipation" (p. 176), he also used the opportunity to chastise the men and women who attempted to downplay Du Bois's radicalism or to deny his embrace of communism at the end of his life. For readers more inclined to celebrate the radical and mute the antidemocratic dimensions of Du Bois's thought, King's admonition ought equally to guide our reading. For the greatest legacy of the questions posed in Du Bois's work and by the figure of Du Bois himself is to remind us just how intricate and complex "our tasks of emancipation" remain.

Corresponding author: Lawrie Balfour, Department of Politics, University of Virginia, P.O. Box 400787, Charlottesville, VA 22904-4787. E-mail: klb3q@virginia.edu

\section{NOTE}

1. I would like to express my gratitude to Jack Turner for his tireless efforts to make this exchange possible and to Cristina Beltrán, Tommie Shelby, Rogers Smith, and Turner for their illuminating comments. Robert Gooding-Williams' Du Bois scholarship, and his work on race and philosophy more broadly, have been essential to my thinking.

\section{REFERENCES}

Allen, Danielle S. (2004). Talking to Strangers: Anxieties of Citizenship Since Brown v. Board of Education. Chicago, IL: University of Chicago Press.

Beltrán, Cristina (2010). The Trouble with Unity: Latino Politics and the Creation of Identity. New York: Oxford University Press.

Davis, Adrienne D. (2010). The Jurisprudence and Justice of Black Reparations: Caste, Slavery, and Transitional Justice. Unpublished Manuscript, Washington University Law School.

De Greiff, Pablo (Ed.) (2006). The Oxford Handbook of Reparations. Oxford, UK: Oxford University Press.

De Greiff, Pablo (2007). Justice and Reparations. In Jon Miller and Rahul Kumar (Eds.), Reparations: Interdisciplinary Inquiries, pp. 153-175. Oxford, UK: Oxford University Press.

Douglass, Frederick ([1855] 2003). My Bondage and My Freedom. Edited with an introduction by John David Smith. New York: Penguin.

Du Bois, W. E. B. ([1904] 1997). "The Development of a People.” In David W. Blight and Robert Gooding-Williams (Eds.), The Souls of Black Folk, pp. 238-254. Boston, MA: Bedford. 


\section{Lawrie Balfour}

Du Bois, W. E. B. ([1935] 1992). Black Reconstruction in America, 1860-1880. New York: Free Press.

Forman, James ([1972] 1997). The Making of Black Revolutionaries. Seattle, WA: University of Washington Press.

Gooding-Williams, Robert (2009). In the Shadow of Du Bois: Afro-Modern Political Thought in America. Cambridge, MA: Harvard University Press.

King, Martin Luther, Jr. (1970). Honoring Dr. Du Bois. In John Henrik Clarke, Esther Jackson, Ernest Kaiser, J. H. O'Dell (Eds.), Black Titan W. E. B. Du Bois: An Anthology by the Editors of Freedomways, pp. 176-183. Boston, MA: Beacon Press.

Seelye, Katharine Q. (2010). Celebrating Secession Without the Slaves. New York Times, November 29, 20.

Smith, Rogers M. (2003). Stories of Peoplehood: The Politics and Morals of Political Membership. Cambridge, UK: Cambridge University Press.

Valls, Andrew (2003). Racial Justice as Transitional Justice. Polity 36(1): 53-71.

Zernike, Kate, Carl Hulse, and Brian Knowlton (2010). At Lincoln Memorial, a Call for Religious Rebirth. New York Times, August 28, 15. 